\section{Local Generation of Angiotensin II as a Mechanism of Regulation of Peripheral Vascular Tone in the Rat}

Juan A. Oliver and Robert R. Sciacca

Department of Medicine, Columbia University College of

Physicians \& Surgeons, New York 10032
A

bstract. Renin is present in vascular smooth muscle cells and has been shown to coexist with angiotensins I (AI) and II (AII) in many cell types. Accordingly, we postulated that the renin-angiotensin system controls vascular tone, not by the action of circulating renal renin but rather, by the local generation of angiotensin by vascular renin. Isolated rat hindquarters were perfused in vitro with Krebs-Henseleit buffer containing 7\% albumin, and flow-adjusted to obtain a perfusion pressure of $\sim 90 \mathrm{mmHg}$. Infusion of $4.8 \mathrm{nmol} \cdot \mathrm{min}^{-1}$ for $5 \mathrm{~min}$ of AII or AI markedly increased perfusion pressure. An identical dose of the synthetic tetradecaptide of renin substrate (TDCP-RS) increased pressure similarly to AI. The pressure increase evoked by TDCP-RS was markedly decreased by captopril and by two different peptides that inhibit renin. Renin activity in the perfusate, incubated with semipurified rat renin substrate, was $21 \pm 3$ $\mathrm{pg} \mathrm{AI} \cdot \mathrm{ml}^{-1} \cdot \mathrm{h}^{-1}($ mean $\pm \mathrm{SEM})$ at $15 \mathrm{~min}$ of perfusion and $47 \pm 4 \mathrm{pg} \mathrm{AI} \cdot \mathrm{ml}^{-1} \cdot \mathrm{h}^{-1}$ at $45 \mathrm{~min}(n=9 ; P<0.01)$. When TDCP-RS was infused at $4.8 \mathrm{nmol} \cdot \mathrm{min}^{-1}$ for 5 min in the presence of captopril, AI in the perfusate increased linearly at a rate of $16.5 \mathrm{pmol} \cdot \mathrm{min}^{-1}$ for 10 $\min (n=5)$. The results indicate that TDCP-RS constricted the vasculature by its conversion to AII and suggest that AII was generated from a two-step hydrolysis of TDCP-RS by renin and converting enzyme. The data thus suggest that the renin-angiotensin system controls vascular tone by the local generation of AII by renin and converting enzyme in the vasculature.

This work was presented in part at the 1983 Annual Meeting of the American Society of Nephrology and has been published in abstract (1984. Kidney Int. 25:334).

Dr. Oliver is an Investigator of the New York Heart Association. Received for publication 20 September 1983 and in revised form 25 June 1984

J. Clin. Invest.

(c) The American Society for Clinical Investigation, Inc. 0021-9738/84/10/1247/05 \$1.00

Volume 74, October 1984, 1247-1251

\section{Introduction}

Renin is a protease that cleaves its substrate to generate the decapeptide angiotensin I (AI), ${ }^{\prime}$ which is, in turn, converted to the octapeptide angiotensin II (AII) by converting enzyme. AII is a potent vasoconstrictor that is required for the maintenance of blood pressure in a variety of conditions such as salt depletion (1) and heart failure (2). Secretion of renin by the kidney increases in these conditions and renin in plasma may act upon its substrate to generate AI. However, renin is present in many organs (3-6) and cell types (7-9), including vascular smooth muscle cells (8); AI and AII and converting enzyme exist in renin-containing cells $(7,9,10)$; and the plasma concentration of AII is in the picomolar range (11), but binding affinities of this peptide to its receptors are in the nanomolar range (12-15). These observations raise questions about the role of circulating renin and angiotensin. Accordingly, in the present study, we tested the hypothesis that the renin-angiotensin system controls vascular tone by the local generation of angiotensin by vascular renin. We show here in an isolated rat hindquarters perfused in vitro that locally produced AII constricts the vasculature. The results suggest that renin and converting enzyme in the peripheral vasculature use circulating renin substrate to locally generate AII and regulate vascular tone.

\section{Methods}

Male Sprague-Dawley rats (250-300 g) were anesthetized with Inactin and given $\sim 5 \mathrm{ml}$ of saline at $37^{\circ} \mathrm{C}$ over $30 \mathrm{~min}$ through a jugular vein catheter. A transverse laparotomy below the costal margins was then performed and both kidneys removed. The urinary bladder was emptied and after ligation, the distal sigmoid was sectioned and displaced to the upper abdomen. A perfusion cannula was introduced in the abdominal aorta just below the renal pedicles and perfusion was begun. A diagram of the perfusion system is shown in Fig. 1. Both hindquarters were isolated by sectioning the animal at the level in which the perfusion cannula was introduced. During the initial 8-10 min of perfusion, the preparation was thoroughly rinsed with 2 liter of saline at $37^{\circ} \mathrm{C}$ while being perfused with $500 \mathrm{ml}$ of modified KrebsHenseleit solution at $37^{\circ} \mathrm{C}$, gassed with $\mathrm{O}_{2} / \mathrm{CO}_{2}(95 \% / 5 \%)$ and containing

1. Abbreviations used in this paper: $\mathrm{AI}$ and $\mathrm{AII}$, angiotensin $\mathrm{I}$ and II, respectively; H77, renin inhibitor His-Pro-Phe-His-Leu-Leu-Val-Tyr; RI, renin inhibitor Pro-His-Pro-Phe-His-Phe-Phe-Val-Tyr-Lys; TDCPRS, tetradecapeptide of renin substrate. 


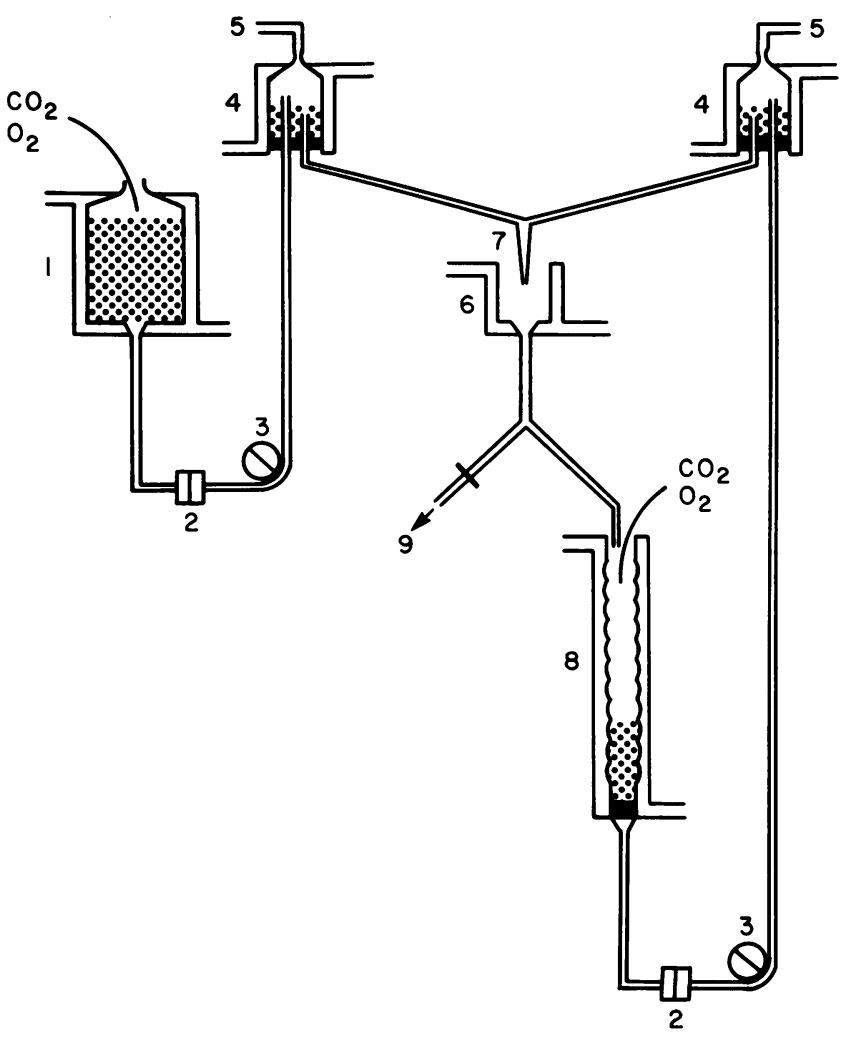

Figure 1. Diagram of perfusion system. 1 , container with preperfusion fluid; 2, 10- $\mu \mathrm{m}$ Millipore filter; 3, perfusion pump; 4, bubble trap chamber; 5 , line to pressure transducer; 6 , chamber containing hindquarters; 7 , perfusion cannula; 8 , oxygenation chamber with perfusate fluid; 9 , outlet.

$90 \mathrm{mg} / 100 \mathrm{ml}$ glucose and 4\% bovine serum albumin (Fraction V, Miles Laboratories, Inc., Elkhart, IN) and $2.4 \mathrm{mM}$ phosphate (16). During this initial washing period the flow was adjusted to obtain a perfusion pressure of $\sim 60 \mathrm{mmHg}$ and the effluent exiting from the vena cava was discarded. Toward the end of this period, the preparation was placed in a water-jacketed container at $37^{\circ} \mathrm{C}(6$ in Fig. 1) and the perfusion was then continued with modified Krebs-Henseleit solution as described above except that the concentration of bovine serum albumin was $7 \%$ and also contained a mixture of amino acids (17). This solution had an initial volume of $150 \mathrm{ml}$ and after discarding the initial $\sim 60 \mathrm{ml}$, it was recirculated for the remainder of the experiment. Flow was adjusted to obtain a perfusion pressure of $\sim 90 \mathrm{mmHg}$. The perfusion apparatus was a modification of that described by DeMello and Maack (17) for kidney perfusion with the exception that there were two perfusion systems that terminated in a single perfusion cannula. Thus, perfusion with the initial washing solution could be followed without interruption with the final perfusate. Pressure was recorded with a Statham transducer interfaced with a Grass recorder.

All experimental maneuvers were carried out after a 20-30-min period of equilibration. At this time, control pressure was determined and immediately afterwards, AI and AII (Sigma Chemical Co., St. Louis, MO) or tetradecapeptide of renin substrate (TDCP-RS) (Peninsula Laboratories, Inc., San Carlos, CA) were administered. These compounds were dissolved in saline and the solution was infused into the perfusate at a rate of $0.21 \mathrm{ml} \cdot \mathrm{min}^{-1}$ resulting in an infusion dose of 4.8 $\mathrm{nmol} \cdot \min ^{-1}$ for $5 \mathrm{~min}$ for all three compounds. A single infusion was performed for each preparation.

In other experiments, the effects of captopril and of two peptide inhibitors of renin on the TDCP-RS action were studied. Captopril (E. R. Squibb \& Sons, Inc., Princeton, NJ) was added $(0.25 \mathrm{mM})$ to the perfusate at the beginning of the perfusion; the renin inhibitor peptide Pro-His-Pro-Phe-His-Phe-Phe-Val-Tyr-Lys (18) (Peninsula Laboratories, Inc.) was added $(26 \mu \mathrm{M})$ to the perfusate $15 \mathrm{~min}$ before the infusion of TDCP-RS or AI; the renin inhibitor peptide His-ProPhe-His-Leu-Leu-Val-Tyr (19) (Ferring Pharmaceuticals, Middlesex, England) was added $(5 \mu \mathrm{M})$ to the perfusate $15 \mathrm{~min}$ before the infusion of TDCP-RS. Captopril and both renin inhibitors were dissolved in saline.

Perfusate $(1 \mathrm{ml})$ for determination of renin activity was collected in tubes containing EDTA $(15 \mathrm{mM})$ and frozen until assayed. $666 \mu 1$ of perfusate were incubated for $5 \mathrm{~h}$ at pH 6.4 as described by Menard and Catt (20) with $250 \mu$ l of a partially purified rat renin substrate preparation containing $0.35 \mu \mathrm{g}$ of renin substrate. Rat renin substrate was prepared as described by Boucher et al. (21). Briefly, plasma was obtained from rats nephrectomized $24 \mathrm{~h}$ previously by collecting blood in syringes moistened with heparin. After separation of plasma from cells by centrifugation at $4^{\circ} \mathrm{C}, 0.1 \mathrm{M} \mathrm{K}_{2}$ EDTA was added and the $\mathrm{pH}$ adjusted to 8. After slow stirring for $1 \mathrm{~h}$ at room temperature, the solution was cooled to $4^{\circ} \mathrm{C}$ and the $\mathrm{pH}$ readjusted to 5.3. The substrate was next salted out by the addition of solid $\left(\mathrm{NH}_{4}\right)_{2} \mathrm{SO}_{4}$ to $2.3 \mathrm{M}$ and stirred for $10 \mathrm{~min}$. After centrifugation, the precipitate was resuspended in distilled water and extensively dialyzed. The specific activity of the renin substrate preparation was $0.09 \mu \mathrm{g}$ of angiotensin I equivalents of renin substrate per milligram of protein. The incubation mixture was assayed for angiotensin I as described elsewhere (22). The preincubation levels of AI were near zero as were levels generated from the renin substrate preparation incubated in the absence of perfusate. The angiotensin I radioimmunoassay has $a B_{10}$ of $5 \mathrm{pg}$ and $a B_{50}$ of $36 \mathrm{pg}$. The interassay coefficient of variation for the determination of renin activity is $13 \%$. When renin was incubated with excess renin substrate, the generation of AI per unit time was constant up to $5 \mathrm{~h}$. All values are expressed as mean \pm SEM. Data were analyzed by analysis of variance or paired $t$ test (22). Differences were termed significant if the $F$ or $t$ value exceeded the critical value for the 5\% level.

\section{Results}

At the beginning of the experiment, flow was adjusted to obtain a perfusion pressure of $90-95 \mathbf{m m H g}$. As shown in Table I, the preparation remained quite stable for at least $45 \mathrm{~min}$.

The hindquarters vasculature readily responded to AII; infusion of this peptide into the perfusate markedly constricted the vasculature, hence increasing the perfusion pressure; the maximal effect was at $2 \mathrm{~min}$ of infusion (Table II). To demonstrate conversion of AI to AII by converting enzyme in the preparation, the pressure response to angiotensin I was

Table I. Characteristics of Hindquarters Preparation

\begin{tabular}{llll}
\hline Time & Pressure & Flow & Renin activity \\
\hline $\min$ & $\mathrm{mmHg}$ & $\mathrm{ml} \cdot \mathrm{min}^{-1}$ & $\mathrm{pg} \mathrm{AI} \cdot \mathrm{ml}^{-1} \cdot \mathrm{h}^{-1}$ \\
15 & $92 \pm 1$ & $98 \pm 5$ & $21 \pm 3$ \\
45 & $92 \pm 1$ & $95 \pm 4$ & $47 \pm 4^{*}$ \\
\hline
\end{tabular}

Values are mean $\pm \mathrm{SEM} ; n=9 .{ }^{*} P<0.01$ vs. $15-\mathrm{min}$ value. 
Table II. Perfusion Pressure ( $\mathrm{mmHg}$ ) during Control and Experimental Maneuvers

\begin{tabular}{|c|c|c|c|c|c|c|}
\hline & \multirow[b]{2}{*}{ Control } & \multicolumn{5}{|l|}{ Min } \\
\hline & & 1 & 2 & 3 & 4 & 5 \\
\hline AII $(n=6)$ & $93 \pm 2$ & $118 \pm 9$ & $135 \pm 10$ & $133 \pm 8$ & $124 \pm 6$ & $119 \pm 6$ \\
\hline $\mathrm{AI}(n=6)$ & $91 \pm 1$ & $102 \pm 4$ & $113 \pm 6$ & $116 \pm 7$ & $114 \pm 6$ & $109 \pm 5$ \\
\hline TDCP-RS $(n=7)$ & $93 \pm 1$ & $100 \pm 2$ & $107 \pm 3$ & $112 \pm 4$ & $116 \pm 3$ & $117 \pm 3$ \\
\hline TDCP-RS + captopril $(n=6)$ & $92 \pm 1$ & $94 \pm 1$ & $95 \pm 1$ & $97 \pm 1$ & $99 \pm 1$ & $100 \pm 2$ \\
\hline TDCP-RS + RI $(n=6)$ & $94 \pm 2$ & $96 \pm 2$ & $99 \pm 2$ & $101 \pm 2$ & $104 \pm 3$ & $106 \pm 4$ \\
\hline $\mathrm{AI}+\mathrm{RI}(n=6)$ & $90 \pm 1$ & $93 \pm 1$ & $100 \pm 3$ & $108 \pm 6$ & $113 \pm 8$ & $115 \pm 8$ \\
\hline TDCP-RS + H77 $(n=6)$ & $93 \pm 1$ & $94 \pm 1$ & $96 \pm 1$ & $98 \pm 2$ & $99 \pm 2$ & $99 \pm 2$ \\
\hline $\mathrm{AI}+\mathrm{H} 77(n=3)$ & $92 \pm 2$ & $100 \pm 3$ & $112 \pm 4$ & $117 \pm 4$ & $119 \pm 4$ & $118 \pm 4$ \\
\hline
\end{tabular}

Values are mean \pm SEM. All treatments resulted in a significant increase in pressure at $5 \min (P<0.01)$.

determined. Table II shows that AI increased perfusion pressure with a maximal effect at $3 \mathrm{~min}$ of infusion. Since angiotensin I has no direct vasoconstrictor effect, this result provides evidence for the generation of AII from AI by the action of converting enzyme present in the vasculature.

To examine whether angiotensin II could be generated from exogenous renin substrate, the TDCP-RS (23) was administered to the hindquarters preparation. As shown in Table II and Fig. 2, infusion of TDCP-RS constricted the vasculature and thus increased perfusion pressure. Its maximal effect was at $5 \mathrm{~min}$ of infusion and its overall action was almost identical to that of AI. The 5-min infusion resulted in a maximal concentration of TDCP-RS in the perfusate of $\sim 0.3 \mu \mathrm{M}$, which is similar to the concentration of native renin substrate in rat plasma (24). The inhibitor of converting enzyme, captopril, markedly inhibited the increase in perfusion pressure by TDCP-RS (Table II and Fig. 2). This result demonstrates that the increase in pressure evoked by TDCP-RS was due to

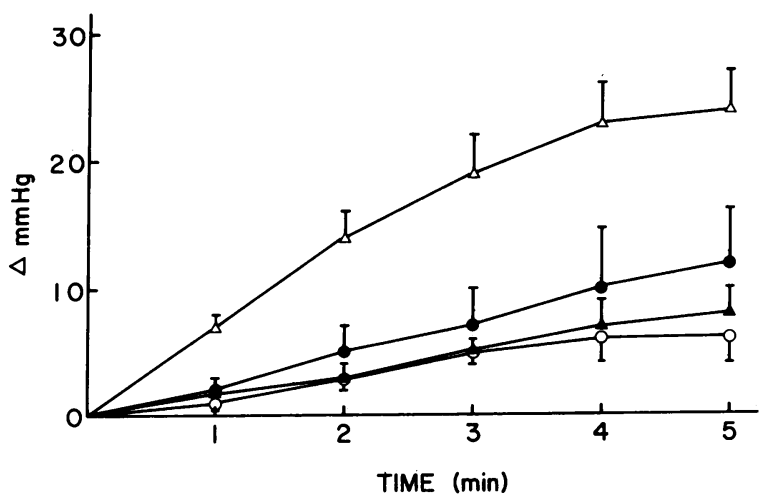

Figure 2. Captopril and both renin inhibitors, RI and H77, significantly inhibited the increase in perfusion pressure elicited by TDCP. RS $(P<0.001) . \Delta \mathrm{mmHg}$ were obtained from experiments detailed in Table II. $\Delta$, TDCP-RS $(n=7)$; $\bullet$, TDCP-RS with RI $(n=6)$; $\Delta$, TDCP-RS with captopril $(n=6)$; O, TDCP-RS with H77 $(n=6)$. Values are mean \pm SEM. generation by converting enzyme of angiotensin II and subsequent vasoconstriction by this peptide.

To determine whether the vasoconstrictor action of TDCPRS was also due to the action of renin, the following experiments were performed. First, we examined whether renin activity was released by the hindquarters into the perfusate. Perfusate collected at 15 and $45 \mathrm{~min}$ was incubated with partially purified rat renin substrate. As shown in Table I, renin activity was measurable at $15 \mathrm{~min}$ of perfusion and increased with time. Second, we examined the effects of the

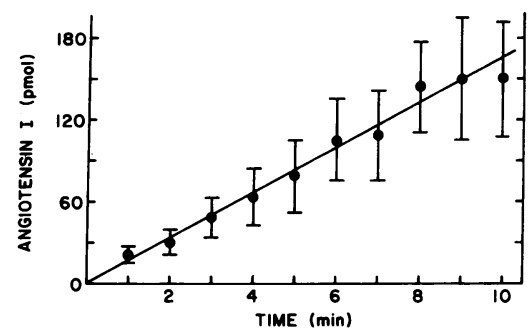

Figure 3. Angiotensin I in the perfusate in five hindquarters preparations. Captopril was added to the perfusate and TDCP-RS was infused for $5 \mathrm{~min}$ as detailed in Methods. During infusion of TDCPRS, perfusate samples $(0.5 \mathrm{ml})$ were collected at 1 - $\mathrm{min}$ intervals in tubes containing EDTA $(15 \mathrm{mM})$ and after adding $10 \mu \mathrm{l}$ of a $5 \%$ solution of phenylmethyl-sulfonylfluoride in ethanol were assayed for AI as detailed in Methods. Because of cross-reactivity of TDCP-RS with the antibody to angiotensin $I\left(0.05 \%\right.$ at $\left.B_{50}\right)$, five sham infusions with TDCP-RS were done under identical conditions with the exception that no hindquarters were being perfused. Samples from these experiments were incubated with the angiotensin I antibody and $\mathrm{I}^{125}$. angiotensin $I$. The mean values of these five experiments were subtracted from the mean values of the five experiments in which hindquarters were perfused. The mean $\pm \mathrm{SEM}$ angiotensin I concentration $\left(\mathrm{pmol} \cdot \mathrm{ml}^{-1}\right)$ of the sham infusions was $0.7 \pm 0.1$ at $1 \mathrm{~min}$, reached a maximum of $2.3 \pm 0.1$ at $5 \mathrm{~min}$, and was $2.1 \pm 0.1$ at 10 $\mathrm{min}$. Corresponding values in the presence of hindquarters were $0.9 \pm 0.1,3.2 \pm 0.3$, and $4.0 \pm 0.5$. Perfusate volume was $90 \mathrm{ml}$. At all time periods, angiotensin $I$ values in the presence of hindquarters were significantly greater than during the sham infusions $(P<0.01)$. Values are mean \pm SEM. 
renin inhibitor Pro-His-Pro-Phe-His-Phe-Phe-Val-Tyr-Lys (RI) (18) and of the renin inhibitor His-Pro-Phe-His-Leu-Leu-ValTyr (H77) (19) on the vasoconstriction caused by TDCP-RS. Table II and Fig. 2 show that the pressure rise evoked by TDCP-RS was markedly blunted by both renin inhibitors. Third, we determined the ability of the preparation to generate AI from TDCP-RS during inhibition of converting enzyme with captopril. As shown in Fig. 3, during a 5-min infusion of TDCP-RS in the presence of captopril, AI in the perfusate increased linearly for $10 \mathrm{~min}(P<0.001)$. The rate of generation of angiotensin I was $16.5 \mathrm{pmol} \cdot \mathrm{min}^{-1}$ as measured by leastsquare fit of the data.

\section{Discussion}

These results indicate that in order to exert its effect, TDCPRS was hydrolyzed to AII in two steps. It is clear that one step was the hydrolysis of AI to AII by converting enzyme since captopril inhibited the vasoconstrictor action of TDCPRS. Several lines of evidence suggest that renin and not some other peptidase was the enzyme responsible for the generation of angiotensin I. First, renin activity was released by the hindquarters into the perfusate and it increased with time (Table I). Similar results have also been shown in the splanchnic circulation (25). Further, renin activity is present in vascular extracts $(26,27)$ and renin has recently been shown to be synthesized by vascular smooth muscle cells (8). Second, two different peptide inhibitors of renin, RI and H77, markedly diminished the vasoconstrictor action of TDCP-RS (Fig. 2) but had little effect on the action of angiotensin I (Table II). ${ }^{2}$ These results make it unlikely that converting enzyme alone could be responsible for the generation of angiotensin II from TDCP-RS (31). Moreover, infusion of TDCP-RS during inhibition of converting enzyme with captopril resulted in generation of AI (Fig. 3). Finally, that TDCP-RS was hydrolyzed to angiotensin I by an enzyme specific for the generation of this peptide, i.e., renin, is suggested by the equipotency of $\mathrm{AI}$ and TDCP-RS. This makes it unlikely that cathepsins or other peptidases were responsible for generating AII nonspecifically from TDCP-RS. Furthermore, these enzymes are inhibited in the presence of albumin (32), and are not affected by captopril $(33,34)$.

These results support the hypothesis that the renin-angiotensin system controls vascular tone by the local generation of angiotensin II by renin and converting enzyme in the vasculature. ${ }^{3}$ An unequivocal demonstration of this hypothesis, however, would require utilization of native renin substrate

2. Although RI has been shown in in vitro conditions to have only weak inhibitory action against rat renin (28), in our experiments, it was almost as effective as $\mathbf{H 7 7}$. However, recent evidence suggests that angiotensin is generated intracellularly $(7,29)$ and the optimum $\mathrm{pH}$ of the renin-renin substrate reaction is $6.5(30)$. It is possible that these renin inhibitors are more effective under these conditions.

3. Although it has recently been shown that vascular smooth muscle cells grown in tissue culture synthesize renin [8], it is possible that under in vivo conditions, renin present in the vasculature may, at least in part, be of renal origin (27). and a specific renin inhibitor, i.e., renin antibody. The data of the present study are in agreement with the work of Swales and Thurston, suggesting that vascular renin contributes to blood pressure maintenance $(27,35)$. Determination of the relative contributions of this vascular renin and of the renin of renal origin circulating in plasma to the generation of angiotensin and control of vascular tone requires further quantitative experiments. However, the results presented here together with the observations that $(a)$ binding affinities of AII to its cellular receptors as well as its cellular actions occur at concentrations in the nanomolar range (12-15) while the concentration of this peptide in plasma is in the picomolar range (11); (b) AI and AII and converting enzyme exist in renin containing cells $(7,9,10) ;(c)$ in the kidney, renin and angiotensin II are secreted into the interstitium $(11,36,37)$; and $(d)$ inhibitors of converting enzyme $(27,38)$ or a specific antibody to renin substrate (39) may lower blood pressure in the absence of kidneys lead us to propose that the reninangiotensin system regulates vascular tone by utilizing circulating renin substrate and subsequent local generation and action of AII. In this view, renin and angiotensin in blood may only be overflow products of a locally acting system in a similar manner to that of circulating norepinephrine and dopamine- $\beta$-hydroxylase. This could explain the effectiveness of converting enzyme inhibitors in lowering blood pressure in forms of hypertension with little renin activity in blood (34).

\section{Acknowledgments}

We thank Dr. Q. Al-Awqati for helpful advice and continuous encouragement, Dr. P. Cannon for support, Dr. T. Maack for help in setting up the perfusion apparatus, Mr. F. Cassidy for technical assistance and Mr. L. Norbert for preparing the manuscript.

This research was supported in part by grant K-116 from New York State Health Research Council and grant HL-31540 from National Institutes of Health.

\section{References}

1. Oliver, J. A., and P. J. Cannon. 1978. The effect of altered sodium balance upon renal vascular reactivity to angiotensin II and norepinephrine in the dog. Mechanism of variation in angiotensin responses. J. Clin. Invest. 61:610-623.

2. Watkins, L., Jr., J. A. Burton, E. Haber, J. R. Catt, F. W. Smith, and A. C. Barger. 1976. The renin-angiotensin-aldosterone system in congestive failure in conscious dogs. J. Clin. Invest. 57:1606-1617.

3. Michelakis, A. M., H. Yoshida, J. Menzie, K. Murakami, and T. Inagami. 1974. A radioimmunoassay for the direct measurement of renin in mice and its application to submaxillary gland and kidney studies. Endocrinology. 94:1101-1105.

4. Inagami, T., D. L. Clements, S. Hirose, T. Okamura, M. Naruse, Y. Takii, and H. Yokosawa. 1982. Brain renin. Clin. Exp. Hypertens. 4:607-622.

5. Naruse, M., and T. Inagami. 1982. Markedly elevated specific renin levels in the adrenal in genetically hypertensive rats. Proc. Natl. Acad. Sci. USA. 79:3295-3299.

6. Poisner, A. M., G. W. Wood, R. Poisner, and T. Inagami. 1982. Renin and inactive renin in human amnion at term pregnancy. Proc. Soc. Exp. Biol. Med. 169:4-6.

7. Okamura, T., D. L. Clemens, and T. Inagami. 1981. Renin, 
angiotensins, and angiotensin-converting enzyme in neuroblastoma cells: evidence for intracellular formation of angiotensins. Proc. Natl. Acad. Sci. USA. 78:6940-6943.

8. Re, R., J. T. Fallon, V. Dzau, S. C. Quay, and E. Haber. 1982. Renin synthesis by canine aortic smooth muscle cells in culture. Life Sci. 30:99-106.

9. Celio, M. R., and T. Inagami. 1981. Angiotensin II immunoreactivity coexists with renin in the juxtaglomerular granular cells of the kidney. Proc. Natl. Acad. Sci. USA. 78:3897-3900.

10. Rightsel, W. A., T. Okamura, T. Inagami, J. A. Pitcock, Y. Takii, B. Brooks, P. Brown, and E. E. Muirhead. 1982. Juxtaglomerular cells grown as monolayer cell culture contain renin, angiotensin Iconverting enzyme, and angiotensin I and II/III. Circ. Res. 50:822829.

11. Bailie, M. D., F. C. Rector, Jr., and D. W. Seldin. 1971. Angiotensin II in arterial and renal venous plasma and renal lymph in the dog. J. Clin. Invest. 50:119-124.

12. Douglas, J., S. Saltman, P. Fredlund, T. Kondo, and K. J. Catt. 1976. Receptor binding of angiotensin II and antagonists. Correlation with aldosterone production by isolated canine adrenal glomerulosa cells. Circ. Res. 38:(Suppl. 2):108-112.

13. Brown, C. A., R. M. Zusman, and E. Haber. 1980. Identification of an angiotensin receptor in rabbit renomedullary interstitial cells in tissue culture. Correlation with prostaglandin biosynthesis. Circ. Res. 46:802-807.

14. Gunther, S., W. Alexander, W. J. Atkinson, and M. A. Gimbrone, Jr. 1982. Functional angiotensin II receptors in cultured vascular smooth muscle cells. J. Cell Biol. 92:289-298.

15. Campanile, C. P., J. K. Crane, M. J. Peach, and J. C. Garrison. 1982. The hepatic angiotensin II receptor. I. Characterization of the membrane-binding site and correlation with physiological response in hepatocytes. J. Biol. Chem. 257:4951-4958.

16. Davalos, M., N. S. Frega, B. Saker, and A. Leaf. 1978. The effect of exogenous and endogenous angiotensin II in the isolated perfused rat kidney. Am. J. Physiol. 235:F605-F610.

17. DeMello, G., and T. Maack. 1976. Nephron function of the isolated perfused rat kidney. Am. J. Physiol. 231:1699-1707.

18. Burton, J., R. J. Cody, Jr., J. A. Herd, and E. Haber. 1980. Specific inhibition of renin by an angiotensinogen analog: studies in sodium depletion and renin-dependent hypertension. Proc. Natl. Acad. Sci. USA. 77:5476-5479.

19. Szelke, M., B. J. Leckie, M. Tree, A. Brown, J. Grant, A. Hallet, M. Hughes, D. M. Jones, and A. F. Lever. 1982. H77: a potent new renin inhibitor. In vitro and in vivo studies. Hypertension. 4(Suppl. II):II-59-II-69.

20. Menard, J., and K. J. Catt. 1972. Measurement of renin activity, concentration and substrate in rat plasma by radioimmunoassay of angiotensin I. Endocrinology. 90:422-430.

21. Boucher, R., J. Menard, and J. Genest. 1967. A micromethod for measurement of renin in the plasma and kidney of rats. Can. J. Physiol. Pharmacol. 45:881-890.

22. Oliver, J. A., J. Pinto, R. R. Sciacca, and P. J. Cannon. 1980. Basal norepinephrine overflow into the renal vein: effect of renal nerve stimulation. Am. J. Physiol. 239:F371-F377.
23. Skeggs, L. T., J. R. Kahn, K. Lentz, and N. P. Shumway. 1957. The preparation, purification and amino acid sequence of a polypeptide renin substrate. J. Exp. Med. 106:439-453.

24. Bouhnik, J., E. Clauser, J. Gardes, P. Corvol, and J. Menard. 1982. Direct radioimmunoassay of rat angiotensinogen and its application to rats in various endocrine states. Clin. Sci. (Lond.). 62:355360.

25. Ganten, D., K. Hayduk, H. M. Brecht, R. Boucher, and J. Genest. 1970. Evidence of renin release or production in splanchnic territory. Nature (Lond.). 226:551-552.

26. Gould, A. B., L. T. Skeggs, and J. R. Kahn. 1964. The presence of renin activity in blood vessel walls. J. Exp. Med. 119:389-400.

27. Thurston, H., J. D. Swales, R. F. Bing, B. C. Hurst, and E. J. Marks. 1979. Vascular renin-like activity and blood pressure maintenance in the rat. Hypertension. 1:643-649.

28. Poulsen, K., E. Haber, and J. Burton. 1976. On the specificity of human renin studies with peptides inhibitors. Biochim. Biophys. Acta. 425:533-537.

29. Naruse, K., T. Inagami, M. R. Celia, R. J. Workman, and Y. Takii. 1982. Immunohistochemical evidence that angiotensin I and II are formed by intracellular mechanism in juxtaglomerular cells. $H y$ pertension. 4(Suppl. II):II70-II74.

30. Figueiredo, A. F. S., Y. Takii, H. Tsuju, K. Kato, and T. Inagami. 1983. Rat kidney renin and cathepsin $\mathrm{D}$ : purification and comparison of properties. Biochemistry. 22:5476-5481.

31. Dorer, F. E., J. R. Kahn, K. E. Lentz, J. Levine, and L. T. Skeggs. 1975. Formation of angiotensin II from tetradecapeptide renin substrate by angiotensin-converting enzyme. Biochem. Pharmacol. 24:1139-1140.

32. Hackenthal, E., R. Hackenthal, and U. Hilgenfeldt. 1978. Isorenin, pseudorenin, cathepsin $\mathrm{D}$ and renin. A comparative enzymatic study of angiotensin-forming enzymes. Biochim. Biophys. Acta. 522:574588.

33. Reilly, C. F., D. A. Tewksbury, N. M. Schechter, and J. Travis. 1982. Rapid conversion of angiotensin I to angiotensin II by neutrophil and mast cell proteinases. J. Biol. Chem. 257:8619-8622.

34. Antonaccio, M. J., and D. W. Cushman. 1981. Drugs inhibiting the renin-angiotensin system. Fed. Proc. 40:2275-2284.

35. Swales, J. D., and H. Thurston. 1973. Generation of angiotensin II at peripheral vascular level: studies using angiotensin II antisera. Clin. Sci. Mol. Med. 45:691-700.

36. Lever, A. F., and W. S. Peart. 1962. Renin and angiotensinlike activity in renal lymph. J. Physiol. (Lond.). 160:548-563.

37. Morgan, T., and J. M. Davis. 1975. Renin secretion at the individual nephron level. Pfuegers Arch. 359:23-31.

38. Veld, A. J. M., I. M. Schicht, F. H. M. Derkx, J. H. B. deBruyn, and M. A. D. H. Schalekamp. 1980. Effects of an angiotensinconverting enzyme (captopril) on blood pressure in anephric subjects. Br. Med. J. 1:288-290.

39. Gardes, J., J. Bouhnik, E. Clauser, P. Corvol, and J. Menard. 1982. Role of angiotensinogen in blood pressure homeostasis. Hypertension. 4:185-189. 